\title{
Crystal structure change in grossular-Si-free katoite solid solution: Oxygen position splitting in katoite
}

\author{
Atsushi KYONO and Shubhi ArORA \\ Division of Earth Evolution Sciences, Faculty of Life and Environmental Sciences, University of Tsukuba, \\ Tsukuba 305-8572, Japan
}

\begin{abstract}
Single crystals of katoite hydrothermally synthesized were examined by single-crystal X-ray diffraction, EPMA, and Raman spectroscopic techniques. The chemical formulas of the katoite fell inside the miscibility gap proposed by Kyritsis et al. (2009). The systematic absences observed through single-crystal X-ray diffraction were completely consistent with the cubic space group $I a \overline{3} d$. In two kinds of katoite with chemical formulas $\mathrm{Ca}_{3} \mathrm{Al}_{2}$ $\left(\mathrm{SiO}_{4}\right)_{0.57}\left(\mathrm{H}_{4} \mathrm{O}_{4}\right)_{2.43}$ and $\mathrm{Ca}_{3} \mathrm{Al}_{2}\left(\mathrm{SiO}_{4}\right)_{0.69}\left(\mathrm{H}_{4} \mathrm{O}_{4}\right)_{2.31}$, the $\mathrm{O}$ atom position was split into two independent crystallographic sites, $\mathrm{O} 1$ and $\mathrm{O} 2$; the $\mathrm{O} 1$ is coordinated with $\mathrm{Si}$, whereas the $\mathrm{O} 2$ forms a tetrahedral interstice. The $a$ lattice parameter monotonically decreased as increasing Si content. The variation lay along a straight line between grossular and $\mathrm{Si}$-free katoite solid solution. The coordination volume of the $T$ site decreased with $\mathrm{Si}$ incorporation into the $T$ site. The coordination volume of $\mathrm{CaO}_{8}$ dodecahedra also decreased with the $\mathrm{Si}$ incorporation into the $T$ site because the edges of the $\mathrm{CaO}_{8}$ dodecahedron are shared with the adjacent $T \mathrm{O}_{4}$ tetrahedra. These contractions lead to a monotonous decrease of the $a$ lattice parameter. The volume of the $\mathrm{AlO}_{6}$ octahedra, on the other hand, increased with the Si incorporation. There were no clear structural constraints resulting in a miscibility gap in the solid solution. A Raman band corresponding to the $\mathrm{OH}$ stretching vibration was observed at $3650 \mathrm{~cm}^{-1}$, but with the substitution of Si for $\mathrm{H}$, a new Raman peak appeared at $3580 \mathrm{~cm}^{-1}$. The two Raman band positions remained unchanged with increasing Si content. These results strongly suggest that there are two types of $\mathrm{OH}$ stretching vibration in siliceous katoite. We therefore conclude that with $\mathrm{Si}$ substitution for $\mathrm{H}$ the $\mathrm{O}$ position is split into two inequivalent sites that correspond to the $\mathrm{SiO}_{4}$ and $\mathrm{H}_{4} \mathrm{O}_{4}$ tetrahedra. The oxygen position splitting in katoite results in the emergence of two Raman bands at 3580 and $3650 \mathrm{~cm}^{-1}$.
\end{abstract}

Keywords: Hydrogrossular, Hydrogarnet substitution, Single-crystal X-ray diffraction, Raman spectroscopy

\section{INTRODUCTION}

The Earth's upper mantle contains small amounts of hydrogen incorporated into nominally anhydrous minerals (NAMs), such as olivine, pyroxene, garnet, and their high-pressure polymorphs (Wilkins and Sabine, 1973; Bell and Rossman, 1992; Ingrin and Skogby, 2000). The NAMs are of great geophysical interest because they potentially introduce a large amount of water in the Earth's mantle, which would significantly change the physical properties of the mantle (Mackwell et al., 1985; Hirth and Kohlstedt, 1996; Huang et al., 2005). In this respect, a hydrogarnet substitution $\left(\mathrm{SiO}_{4} \leftrightarrow \mathrm{H}_{4} \mathrm{O}_{4}\right)$ is a highly effective mechanism for incorporating hydrogen into the silicate minerals (Cohen-Addad et al., 1964, 1967; Ackermann et al., 1983; Passaglia and Rinaldi,

doi:10.2465/jmps. 190424

A. Kyono, kyono@geol.tsukuba.ac.jp Corresponding author
1984; Sacerdoti and Passaglia, 1985; Geiger et al., 1991). Garnets are hence considered one of the most important hydrogen reservoirs in the Earth's mantle owing to their abundance and stability.

Following the nomenclature proposed by Passaglia and Rinaldi (1984), the hydrogrossular $\mathrm{Ca}_{3} \mathrm{Al}_{2}\left(\mathrm{SiO}_{4}\right)_{3-x}$ $\left(\mathrm{H}_{4} \mathrm{O}_{4}\right)_{x}(0<x \leq 3)$ with a grossular component $\geq 50 \%$ (i.e., $1.5 \geq x>0$ ) is called hibschite, whereas that with a grossular component $<50 \%$ (i.e., $1.5<x \leq 3$ ) is called katoite. The thermal stability and composition dependence of the $a$ lattice parameters in the solid solution have been investigated since the 1940s (Flint et al., 1941; Shoji, 1974; Kobayashi and Shoji, 1982; Lager et al., 1989; Cheng et al., 1990; Kyritsis et al., 2009; Dilnesa et al., 2014). It has been long recognized that a miscibility gap occurs in the solid solution between grossular $\mathrm{Ca}_{3} \mathrm{Al}_{2}$ $\left(\mathrm{SiO}_{4}\right)_{3}$ and $\mathrm{Si}$-free katoite $\mathrm{Ca}_{3} \mathrm{Al}_{2}\left(\mathrm{H}_{4} \mathrm{O}_{4}\right)_{3}$ at low silica substitutions (Shoji, 1974; Jappy and Glasser, 1991; Bennett et al., 1992; Kyritsis et al., 2009; Dilnesa et al., 2014). 
Shoji (1974) conducted hydrothermal experiments over a wide temperature range and concluded that a miscibility gap exists within the siliceous katoite region between $\mathrm{Ca}_{3} \mathrm{Al}_{2}\left(\mathrm{SiO}_{4}\right)_{0.4}\left(\mathrm{H}_{4} \mathrm{O}_{4}\right)_{2.6}$ and $\mathrm{Ca}_{3} \mathrm{Al}_{2}\left(\mathrm{SiO}_{4}\right)_{1.0}\left(\mathrm{H}_{4} \mathrm{O}_{4}\right)_{2.0}$. Recently, Kyritsis et al. (2009) also investigated the miscibility gap by conducting hydrothermal experiments within a temperature range of $200-350{ }^{\circ} \mathrm{C}$. As a result, they demonstrated that a miscibility gap occurs between Si-free katoite $\mathrm{Ca}_{3} \mathrm{Al}_{2}\left(\mathrm{H}_{4} \mathrm{O}_{4}\right)_{3}$ and $\mathrm{Ca}_{3} \mathrm{Al}_{2}\left(\mathrm{SiO}_{4}\right)_{0.8}$ $\left(\mathrm{H}_{4} \mathrm{O}_{4}\right)_{2.2}$. Dilnesa et al. (2014), on the other hand, analyzed the compositional variation of calcium aluminum hydrates during the hydration of calcium aluminate cement at $20{ }^{\circ} \mathrm{C}$. The authors reported that a miscibility gap lies between $\mathrm{Ca}_{3} \mathrm{Al}_{2}\left(\mathrm{SiO}_{4}\right)_{0.41}\left(\mathrm{H}_{4} \mathrm{O}_{4}\right)_{2.59}$ and $\mathrm{Ca}_{3} \mathrm{Al}_{2}$ $\left(\mathrm{SiO}_{4}\right)_{0.84}\left(\mathrm{H}_{4} \mathrm{O}_{4}\right)_{2.16}$. Furthermore, an ab initio calculation has theoretically suggested that the $\mathrm{O}$ atoms in the solid solution are unambiguously split into $\mathrm{SiO}_{4}$ and $\mathrm{H}_{4} \mathrm{O}_{4}$ tetrahedral $(T)$ sites, indicating symmetry lowering (Lacivita et al., 2015; Adhikari et al., 2017). Siliceous katoite is therefore more complicated than $\mathrm{Si}$-free katoite. Variation of crystal structure of the hydrogrossular has however been few systematic investigations. To our knowledge, so far five types of natural hydrogrossular belonging to the solid solution have thus far been investigated using a single-crystal X-ray diffraction method (Basso et al., 1983; Sacerdoti and Passaglia, 1985; Ganguly et al., 1993; Ferro et al., 2003; Chakhmouradian et al., 2008).

In this study, we hydrothermally synthesized single crystals of katoite and examined them using single-crystal X-ray diffraction, EPMA, and Raman spectroscopic techniques. These data are further compared to the other hydrogrossulars published in the literature. Herein, we discuss the crystal structure changes in the solid solution between grossular and $\mathrm{Si}$-free katoite, and report the oxygen position splitting with a $\mathrm{Si}$ substitution for $\mathrm{H}$ in the katoite.

\section{EXPERIMENTAL METHODS}

Commercially available $\mathrm{CaO}$ (Wako Pure Chemical Co., Ltd., purity $\geq 99.9 \%$ ) and $\mathrm{Al}$ (Nirako Co., Ltd., purity $\geq 99.8 \%$ ) were used as the starting materials. Amorphous silica $\mathrm{SiO}_{2}$ (Wako Pure Chemical, purity $>99.5 \%$ ) and tetramethylsilane $\mathrm{Si}\left(\mathrm{CH}_{3}\right)_{4}$ (Shin-Etsu Chemical Co., Ltd., purity $\geq 99.9 \%$ ) were used as the silica source. The starting material for $\mathrm{Si}$-free katoite consisted of $\mathrm{CaO}$ and $\mathrm{Al}$ at a molar ratio of 3:2. In the first run (Run 1), single-crystals of the katoite were prepared by mixing $\mathrm{CaO}, \mathrm{Al}$, and amorphous silica at a molar ratio of $3: 2: 1$. They were carefully mixed using an agate mortar. About $200 \mathrm{mg}$ of the mixture were then transferred into a Teflon vessel and filled with distilled water until $60 \%$ of a total volume of 28 $\mathrm{ml}$. The vessel was placed in a stainless-steel autoclave to conduct the hydrothermal treatment at $250{ }^{\circ} \mathrm{C}$ for 4 days. In the second run (Run 2), about $180 \mathrm{mg}$ of the mixture of $\mathrm{CaO}$ and $\mathrm{Al}$ with 3:2 molar ratio were put into the Teflon vessel with about $1 \mathrm{~g}$ of tetramethylsilane. The vessel was filled with distilled water and then sealed in the stainlesssteel autoclave. Subsequently, the autoclave was hydrothermally heated at $250{ }^{\circ} \mathrm{C}$ for 4 days. After the hydrothermal treatments, the samples were finally recovered through filtration and dried at room temperature.

For the single-crystal X-ray diffraction measurements, suitable single crystals were selected under a microscope and mounted on top of a fine glass fiber. Preliminary experiments on the quality of the crystallinity were performed using a single-crystal synchrotron $\mathrm{X}^{-}$ ray diffraction (XRD) technique at the BL10A beamline of Photon Factory (PF), KEK, Japan. XRD measurements were conducted using a single-crystal diffractometer (SMART APEX II ULTRA; Bruker AXS Inc., Germany) equipped with a CCD detector, multilayer optics, and graphite monochromated $\operatorname{MoK} \alpha$ radiation $(\lambda=$ $0.71073 \AA$ ) generated using a rotating anode. All measurements were carried out at room temperature. Thirtysix frames of two-dimensional diffraction images were collected and processed to obtain the cell parameters and orientation matrix. A total of 720 frames covering a hemisphere of the reciprocal space were collected at a step size of $0.5^{\circ}$ in $\omega$ at three different $\phi$ settings and a detector position of $-28^{\circ}$ in $2 \theta$. The exposure time was $10 \mathrm{~s}$ per frame. Intensity data were integrated and corrected for the Lorentz polarization effects using APEX2 software (Bruker, 2006). The collected data were reduced using the SAINT software package (Bruker, 2008). An empirical absorption correction was also applied using SADABS software (Sheldrick, 1999). The structures were solved through a combination of a direct method and different Fourier methods provided by the program package SHELXTL (Bruker, 1998) and were refined using a full matrix least squares method on $F^{2}$ through SHELXL-2014/7 software (Sheldrick, 2014). Since we finally failed to determine the positions of $\mathrm{H}$ atoms, $\mathrm{H}$ atoms were not included in the calculations. The hydroxyl groups were refined as oxygen atoms in the refinements. All atoms were refined on the basis of anisotropic displacement model.

After single-crystal X-ray diffraction measurements, the single crystals were carefully soaked in acetone to remove them from the glass fibers. They were then transferred on carbon tape and sputter coated with a Pt-Pd alloy for a chemical analysis. A quantitative analysis was conducted using an electron probe micro-analyzer (JXA-8530F, JEOL Ltd., Japan) equipped with a wave- 
length-dispersive $\mathrm{X}$-ray spectrometer. The samples were probed with an acceleration voltage of $15 \mathrm{kV}$, an irradiation current of $10 \mathrm{nA}$, and a beam diameter of $1 \mu \mathrm{m}$. Raw data were corrected using a conventional ZAF program. Wollastonite $\mathrm{CaSiO}_{3}(\mathrm{CaK \alpha})$, aluminum oxide $\mathrm{Al}_{2} \mathrm{O}_{3}(\mathrm{~A} 1 K \alpha)$, and quartz $\mathrm{SiO}_{2}(\mathrm{Si} K \alpha)$ were used as the standards. The contents of $\mathrm{OH}$ were estimated as the difference from $100 \mathrm{wt} \%$. The chemical compositions were calculated from the averages of the several points analyzed. The numbers of $\mathrm{Ca}, \mathrm{Al}, \mathrm{Si}$, and $\mathrm{H}$ cations were determined on the basis of 12 oxygen atoms.

Raman spectra were recorded at room temperature using a micro-Raman spectrometer (NRS-5100, Japan Spectroscopic Co., Japan) equipped with a grating of 1800 lines/mm and a high sensitivity cooled CCD detector. The sample was excited with a green laser operating at $532.12 \mathrm{~nm}$. The incident laser power was kept at less than $5.4 \mathrm{~mW}$ to prevent a dehydration of the katoite. A $100 \times$ objective lens was used to focus the laser beam onto a spot of about a $1 \mu \mathrm{m}$. The Raman spectra were obtained with an integration time of $60 \mathrm{~s}$, and five spectra were averaged. The resolution of the spectra was below $0.5 \mathrm{~cm}^{-1}$. The laser beam produced no visible damage on the surface of the sample during the measurements. The peak positions were determined using least-squares fitting software PeakFit ${ }^{\mathrm{TM}}$ (AISN, 1995) with Lorentzianshaped functions.

\section{RESULTS AND DISCUSSION}

\section{Crystal structure analysis}

As can be seen in Figure 1, katoite obtained from Run 2 comprised euhedral single crystals of approximately 100 $\mu \mathrm{m}$ in diameter. It exhibited an octahedral habit with welldeveloped $\{111\}$ crystal faces. That from Run 1, on the other hand, resulted in much smaller single crystals of approximately $10-20 \mu \mathrm{m}$ in diameter, which was susceptible to rapid electron beam damage occurring on the katoite surface. The tetramethylsilane could be therefore regarded

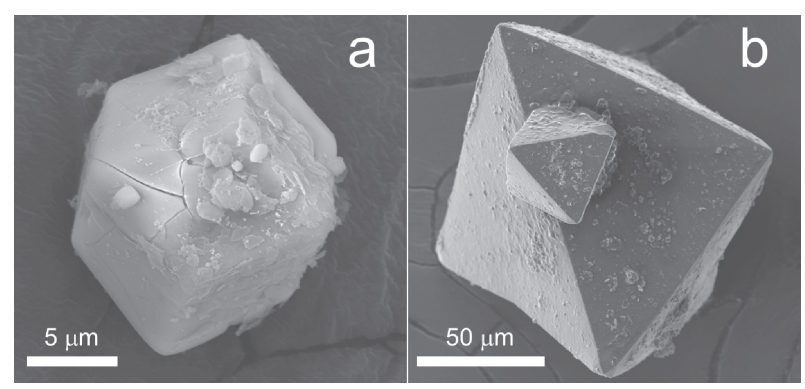

Figure 1. Single crystals of katoite grown from (a) Run 1 and (2) Run 2. as a suitable silica source for growing katoite single crystals. This might be because the molecular structure of tetramethylsilane is also composed of an isolated tetrahedral unit $\mathrm{Si}\left(\mathrm{CH}_{3}\right)_{4}$, which is a substantially common feature of a garnet structure categorized as nesosilicate.

The garnet structure is composed of alternating $T_{\mathrm{O}}$ tetrahedron and $\mathrm{AlO}_{6}$ octahedron, which share corners to form a continuous three dimensional network (Fig. 2). The edges of the $\mathrm{TO}_{4}$ tetrahedron are shared with that of the $\mathrm{CaO}_{8}$ dodecahedron. It is important to bear in the mind that the $\mathrm{CaO}_{8}$ dodecahedron is also directly affected by the variation of the tetrahedral volume. Recently, the ab initio calculation suggested that symmetry lowering from cubic to tetragonal occurs in the hydrogrossular (Lacivita et al., 2015; Adhikari et al., 2017). The hydrogarnet-related mineral henritermierite, i.e., $\mathrm{Ca}_{3} \mathrm{Mn}_{2}^{3+}\left(\mathrm{SiO}_{4}\right)_{2}(\mathrm{OH})_{4}$, crystallizes into tetragonal $\mathrm{I}_{1} / \mathrm{acd}$, whose structure possesses an ordered arrangement of $\mathrm{SiO}_{4}$ and $\mathrm{H}_{4} \mathrm{O}_{4}$ tetrahedra (Armbruster et al., 2001). First, we therefore considered the possibility that the cubic $I a \overline{3} d$ symmetry is lowered to a tetragonal $\mathrm{I}_{1} /$ acd with $\mathrm{Si}$ incorporation into the $\mathrm{Si}$-free katoite. Figure 3 shows precession images reconstructed from the full dataset. No reflections of type $h 00$ with $h=$ $2 n$ corresponding to the reflection conditions of the tetragonal $I 4_{1} /$ acd were observed in the study. The systematic absences observed using the single-crystal X-ray diffraction method were completely consistent with those of the cubic space group $I a \overline{3} d$. The result suggests that no lowering of the symmetry occurs in the katoite.

Next, Armbruster and Lager (1989) proposed a splitoxygen model to account for an increase in the mean-

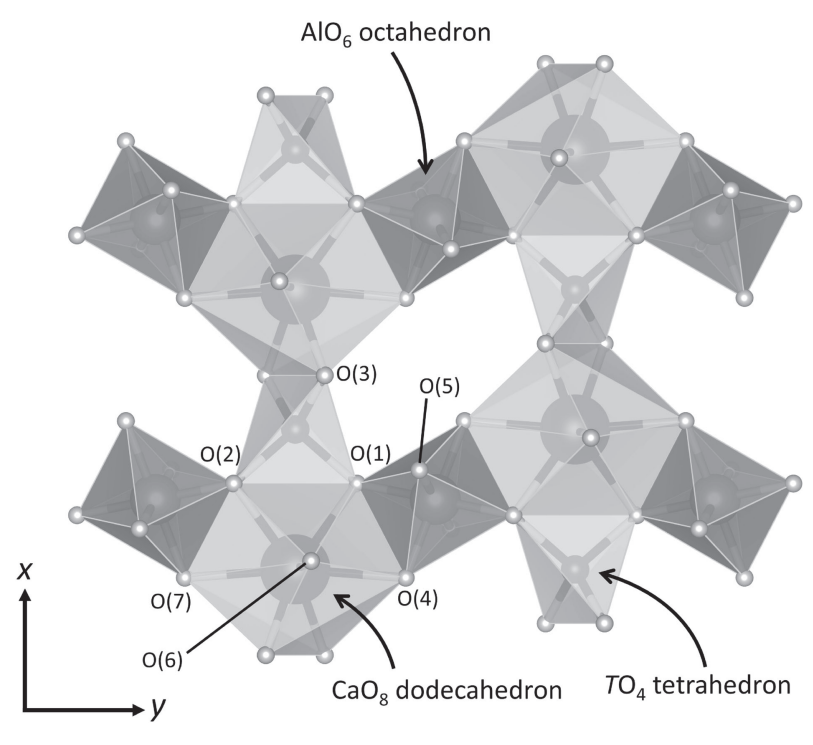

Figure 2. Crystal structure of katoite illustrating the polyhedral configuration projected along the [001] direction. The numbers in the parenthesis after the oxygen atoms represent the symmetry codes listed in Table 5. 

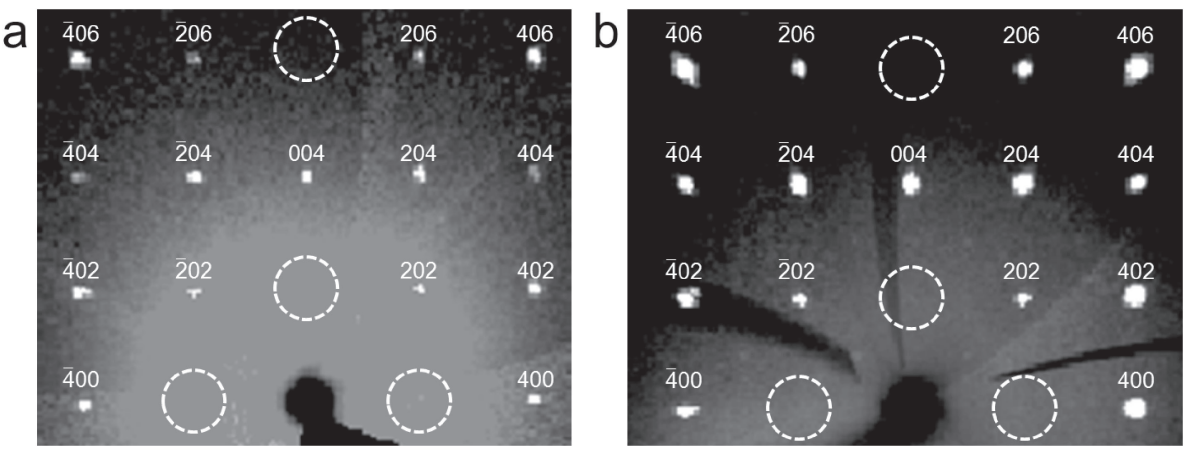

Figure 3. Precession images of $h 0 l$ diffraction plane reconstructed from the experimental datasets from (a) Run 1_2 and (b) Run 2_3. The dotted circles indicate the regions in which the diffraction spots from tetragonal $I 4_{1} /$ acd should appear.

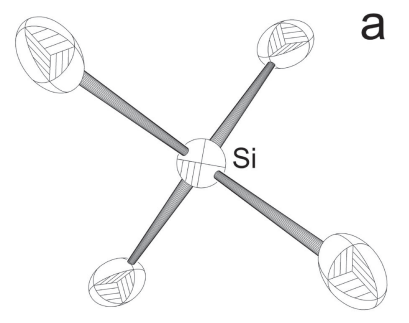

a

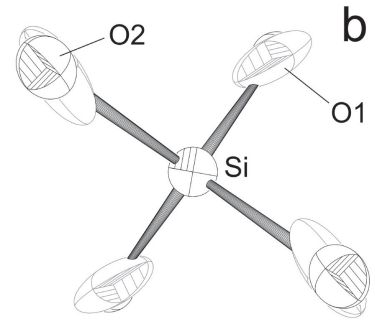

Figure 4. ORTEP plots (Burnett and Johnson, 1996) for Run 23 drawn using (a) unsplit oxygen model and (b) split oxygen model. Displacement ellipsoids are drawn at a 70\% probability level. $\mathrm{O} 1$ bonds to $\mathrm{Si}$, while $\mathrm{O} 2$ forms a tetrahedral vacancy. Color version is available online from https://doi.org/10.2465/jmps. 190424.

square displacement amplitude of oxygen along the $\mathrm{Si}-\mathrm{O}$ bonds. Ferro et al. (2003) adopted the positional disorder of $\mathrm{O}$ atoms into naturally occurring katoite, whose chemical formula was $\mathrm{Ca}_{2.95} \mathrm{Fe}_{0.03} \mathrm{Al}_{2.03}\left(\mathrm{SiO}_{4}\right)_{1.12}\left(\mathrm{H}_{4} \mathrm{O}_{4}\right)_{1.88}$. In our study, because the slight anisotropy of displacement parameter was observed along the $\mathrm{Si}-\mathrm{O}$ bonds (Fig. 4a), we attempted to apply the split-oxygen model. As a result, the model was successfully refined for the datasets from both Run 2_2 and Run 2_3. An ORTEP plot (Burnett and Johnson, 1996) drawn using the split-oxygen model is shown in Figure $4 \mathrm{~b}$. In the split-oxygen model, the $\mathrm{O} 1$ atoms directly bonded to Si exhibit a much stronger anisotropy of the atomic displacement amplitude, whereas the $\mathrm{O} 2$ atoms have a nearly isotropic thermal motion. Figure 5 shows a three-dimensional difference Fourier map around the tetrahedral coordination in the split-O model of Run 2_3. The highest residual density peak of $0.28 \mathrm{e} / \AA^{3}$ was located near the $\mathrm{O} 1$ and $\mathrm{O} 2$ atoms. Although the residual densities around the $\mathrm{O}$ atoms must be ascribed to the $\mathrm{H}$ atoms, we finally failed to determine the $\mathrm{H}$ atom position in the refinements. It would be difficult to obtain a reliable $\mathrm{H}$ position in this split-oxygen model using a conventional X-ray diffraction method because of the low X-ray scattering potential of an $\mathrm{H}$ atom.

For the datasets from Run 1_2 and Run 1_4, by contrast, the split-oxygen model could not be refined us-

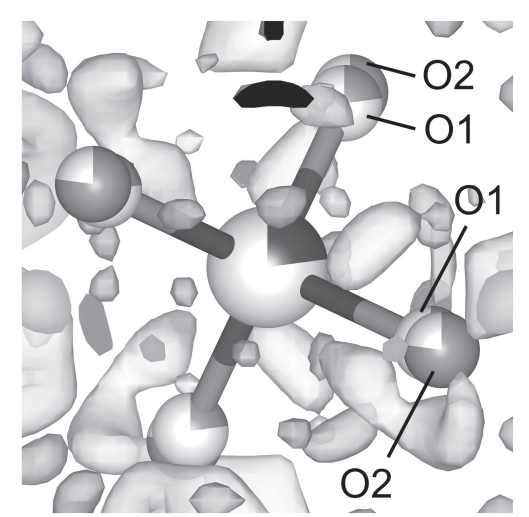

Figure 5. Three-dimensional difference Fourier map showing the tetrahedral coordination in the split-O model of Run $2 \_3$ projected along the [100] direction. The positive and negative difference peaks are represented as yellow and blue, respectively. Color version is available online from https://doi.org/10.2465/ jmps. 190424 .

ing anisotropic displacement parameters. The refinements of the model with isotropic displacement parameters yielded unacceptably short bond lengths between the $\mathrm{Si}$ and $\mathrm{O}$ atoms. Hence, the crystal structures of katoite obtained from Run 12 and Run 144 were refined using an unsplit-oxygen model. The crystallographic data, data collection, and details on the structure refinement are shown in Table 1. All atomic positions, equivalent isotropic displacement parameters, and anisotropic displacement parameters listed in Tables 2 and 3 converged to reasonable values.

Kyritsis et al. (2009) conducted hydrothermal experiments at similar temperatures to our study, although cement, silica flour, and $\alpha$-alumina were used as the starting materials. The authors consequently reported that a miscibility gap in the solid solution extends from the $\mathrm{Si}^{-}$ free katoite $\mathrm{Ca}_{3} \mathrm{Al}_{2}\left(\mathrm{H}_{4} \mathrm{O}_{4}\right)_{3}$ to $\mathrm{Ca}_{3} \mathrm{Al}_{2}\left(\mathrm{SiO}_{4}\right)_{0.8}\left(\mathrm{H}_{4} \mathrm{O}_{4}\right)_{2.2}$. It is important to note that the chemical formulas obtained in this study ranged from Si-free katoite $\mathrm{Ca}_{3} \mathrm{Al}_{2}\left(\mathrm{H}_{4} \mathrm{O}_{4}\right)_{3}$ to $\mathrm{Ca}_{3} \mathrm{Al}_{2}\left(\mathrm{SiO}_{4}\right)_{0.69}\left(\mathrm{H}_{4} \mathrm{O}_{4}\right)_{2.31}$, which completely fell within the miscibility gap proposed by Kyritsis et al. (2009). As mentioned later, there seemed to be no clear geometrical 
Table 1. The crystallographic data, data collection, and structural refinement details for katoite

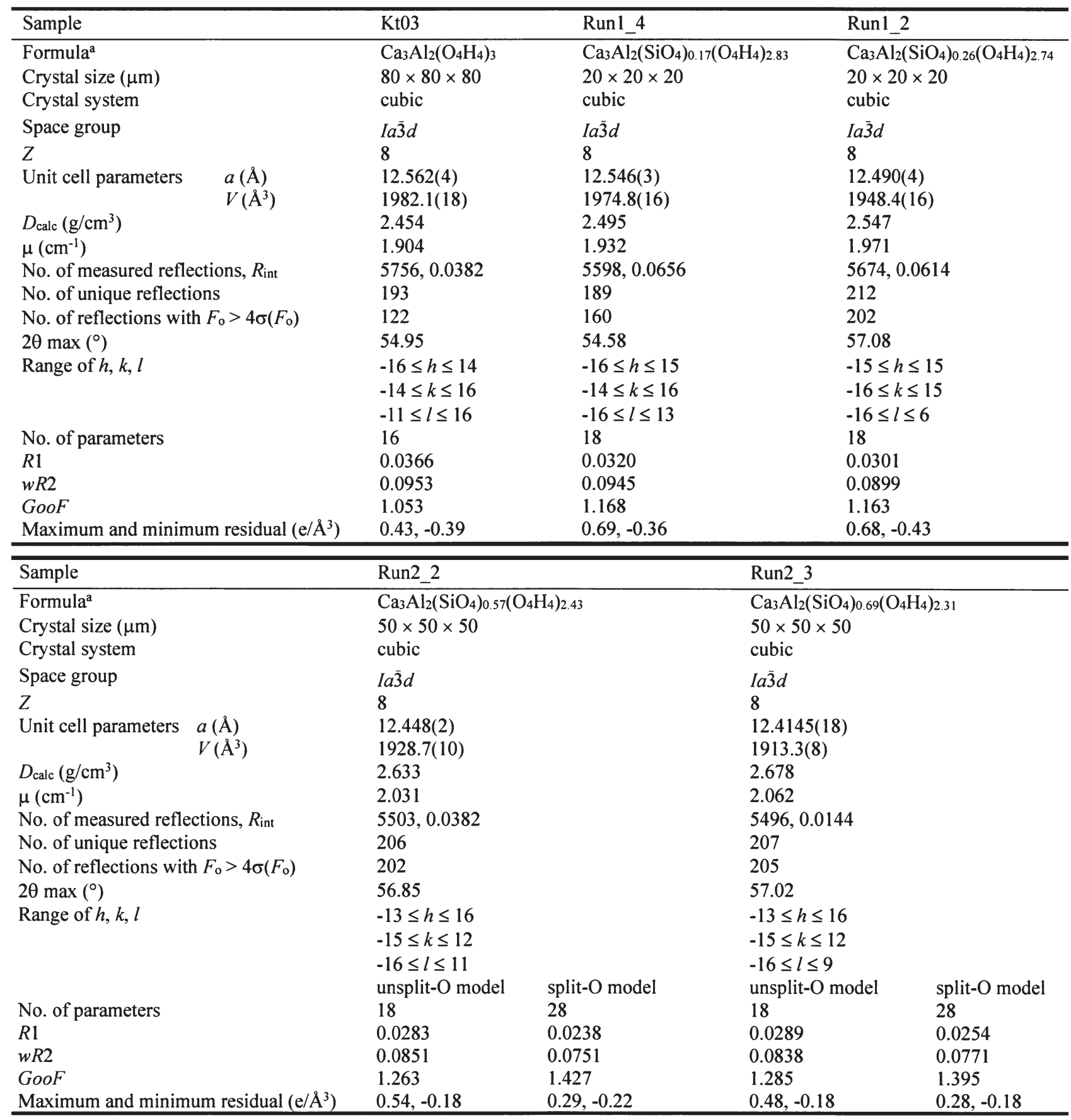

a The chemical formulas of Run1_4 and Run1_2 are calculated from the site occupancy parameters in Table 2.

constraints resulting in a miscibility gap. The appearance and width of a miscibility gap will therefore depend on the starting materials for katoite.

Figure 6 shows the variation of the $a$ lattice parameter as a function of the $\mathrm{Si}$ content. The miscibility gap proposed by Kyritsis et al. (2009) is also shown in Figure 6 . It is known that a decrease in the $a$ lattice parameter with the Si content is characteristic of the solid solution
(Shoji, 1974; Cheng et al., 1990; Jappy and Glasser, 1991; Ferro et al., 2003; Kyritsis et al., 2009; Dilnesa et al., 2014). In this study, the $a$ lattice parameter linearly decreased with the Si content, which is in good agreement with the previous studies (Jappy and Glasser, 1991; Kyritsis et al., 2009; Dilnesa et al., 2014). The chemical formula of katoite described by Sacerdoti and Passaglia (1985) has $0.64 \mathrm{Si}$ apfu, as indicated by the 
Table 2. Atomic coordinates, site occupancy factors, and isotropic atomic displacement parameters $\left(\AA^{2}\right)$ for katoite

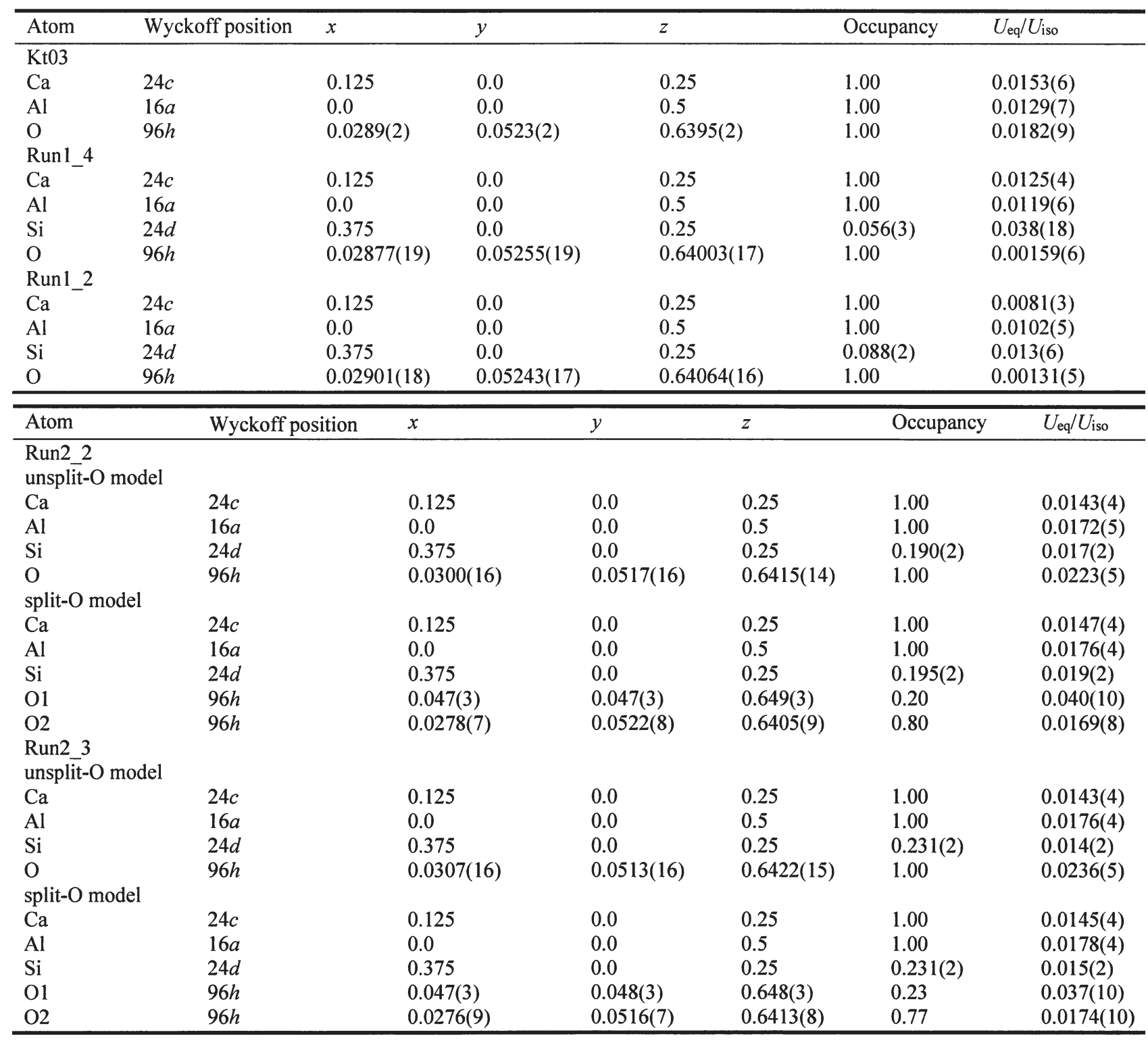

open circle in Figure 6. This is close to that of Run 2_3 (0.69 Si apfu). However, the $a$ lattice parameter for Sacerdoti and Passaglia's katoite, $a=12.38(1) \AA$, is apparently smaller than that of Run 2_3. There is thus far no clear reason for the gap, although one of the causes might be due to the crystallization conditions of the katoite. The selected interatomic distances and polyhedral volumes in grossular-Si-free katoite solid solution are summarized in Tables 4 and 5. The variations are shown in Figures 7 and 8. There was a strong linear correlation between the $\mathrm{Si}$ content and the $\mathrm{TO}_{4}$ tetrahedral volume (Fig. 7). In addition, the $\mathrm{O}(1)-\mathrm{O}(2)$ and $\mathrm{O}(1)-\mathrm{O}(3)$ edges of the $\mathrm{TO}_{4}$ tetrahedron were significantly decreased with the Si content (Fig. 8). The most notable characteristic in the solid solution was shrinkage of the $\mathrm{TO}_{4}$ tetrahedron as a function of the Si content. This structural feature can be explained by a decrease in the electrostatic repulsion between $\mathrm{H}$ atoms. The shrinkage of the $\mathrm{TO}_{4}$ tetrahedron was followed by the decrease in the $\mathrm{CaO}_{8}$ dodecahedral volume (Fig. 7) because the edges of the $\mathrm{TO}_{4}$ tetrahedron are shared with that of the $\mathrm{CaO}_{8}$ dodecahedron (Fig. 2). These continuous shrinkages of the $\mathrm{TO}_{4}$ tetrahedron and $\mathrm{CaO}_{8}$ dodecahedron lead to a decrease of the $a$ lattice parameter. The $\mathrm{AlO}_{6}$ octahedra, on the other hand, have no shared edges with the $\mathrm{TO}_{4}$ tetrahedra (Fig. 2). Thus, it can be anticipated that the $\mathrm{Al}-\mathrm{O}$ bond length remains constant in the solid solution (Sacerdoti and Passaglia 1985; Lager et al., 1989; Ferro et al., 2003;). Indeed, the $\mathrm{AlO}_{6}$ octahedron was only slightly affected by the hydrogarnet substitution, although we found a slight increasing trend 
Table 3. Anisotropic atomic displacement parameters $\left(\AA^{2}\right)$ for katoite

\begin{tabular}{|c|c|c|c|c|c|c|}
\hline Atom & $U_{11}$ & $U_{22}$ & $U_{33}$ & $U_{23}$ & $U_{13}$ & $U_{12}$ \\
\hline \multicolumn{7}{|l|}{$\mathrm{Kt03}$} \\
\hline $\mathrm{Ca}$ & $0.0182(10)$ & $0.0138(6)$ & $0.0138(6)$ & $0.0019(7)$ & 0 & 0 \\
\hline $\mathrm{Al}$ & $0.0129(7)$ & $0.0129(7)$ & $0.0129(7)$ & $0.0001(7)$ & $-0.0001(7)$ & $-0.0001(7)$ \\
\hline $\mathrm{O}$ & $0.0227(19)$ & $0.0173(17)$ & $0.0145(16)$ & $-0.0019(13)$ & $0.0015(13)$ & $-0.0012(12)$ \\
\hline \multicolumn{7}{|c|}{ Run1_4 } \\
\hline $\mathrm{Ca}$ & $0.0152(6)$ & $0.0112(4)$ & $0.0112(4)$ & $0.0015(4)$ & 0 & 0 \\
\hline $\mathrm{Al}$ & $0.0119(6)$ & $0.0119(6)$ & $0.0119(6)$ & $-0.0013(5)$ & $0.0013(5)$ & $0.0013(5)$ \\
\hline $\mathrm{Si}$ & $0.05(3)$ & $0.031(19)$ & $0.031(19)$ & 0 & 0 & 0 \\
\hline $\mathrm{O}$ & $0.0181(12)$ & $0.0170(12)$ & $0.0125(11)$ & $-0.0029(9)$ & $0.0015(8)$ & $-0.0012(9)$ \\
\hline \multicolumn{7}{|c|}{ Run1 2 } \\
\hline $\mathrm{Ca}$ & $0.0093(5)$ & $0.0074(4)$ & $0.0074(4)$ & $0.0006(4)$ & 0 & 0 \\
\hline $\mathrm{Al}$ & $0.0102(5)$ & $0.0102(5)$ & $0.0102(5)$ & $-0.0016(4)$ & $0.0016(4)$ & $0.0016(4)$ \\
\hline $\mathrm{Si}$ & $0.007(9)$ & $0.016(8)$ & $0.016(8)$ & 0 & 0 & 0 \\
\hline $\mathrm{O}$ & $0.0170(10)$ & $0.0120(10)$ & $0.0105(10)$ & $-0.0019(8)$ & $0.0034(8)$ & $-0.0008(8)$ \\
\hline \multicolumn{7}{|c|}{$\begin{array}{l}\text { Run2_2 } \\
\text { unsplit-O model }\end{array}$} \\
\hline $\mathrm{Ca}$ & $0.0169(5)$ & $0.0130(4)$ & $0.0130(4)$ & $0.0019(3)$ & 0 & 0 \\
\hline $\mathrm{Al}$ & $0.0172(5)$ & $0.0172(5)$ & $0.0172(5)$ & $-0.0026(3)$ & $0.0026(3)$ & $0.0026(3)$ \\
\hline $\mathrm{Si}$ & $0.019(4)$ & $0.017(3)$ & $0.017(3)$ & 0 & 0 & 0 \\
\hline \multirow{2}{*}{\multicolumn{7}{|c|}{ split-O model }} \\
\hline & & & & & & \\
\hline $\mathrm{Ca}$ & $0.0171(5)$ & $0.0135(4)$ & $0.0135(4)$ & $0.0019(2)$ & 0 & 0 \\
\hline $\mathrm{Al}$ & $0.0176(4)$ & $0.0176(4)$ & $0.0176(4)$ & $-0.0028(3)$ & $0.0028(3)$ & $0.0028(3)$ \\
\hline $\mathrm{Si}$ & $0.019(3)$ & $0.019(3)$ & $0.019(3)$ & 0 & 0 & 0 \\
\hline $\mathrm{O} 1$ & $0.05(2)$ & $0.035(11)$ & $0.030(15)$ & $-0.019(9)$ & $0.018(14)$ & $-0.007(11)$ \\
\hline $\mathrm{O} 2$ & $0.0172(17)$ & $0.0174(16)$ & $0.0159(15)$ & $-0.0022(11)$ & $0.0027(12)$ & $-0.0022(11)$ \\
\hline \multicolumn{7}{|c|}{$\begin{array}{l}\text { Run2_3 } \\
\text { unsplit-O model }\end{array}$} \\
\hline $\mathrm{Ca}$ & $0.0161(5)$ & $0.0133(4)$ & $0.0133(4)$ & $0.0023(3)$ & 0 & 0 \\
\hline $\mathrm{Al}$ & $0.0176(4)$ & $0.0176(4)$ & $0.0176(4)$ & $-0.0031(3)$ & $0.0031(3)$ & $0.0031(3)$ \\
\hline $\mathrm{Si}$ & $0.015(3)$ & $0.014(2)$ & $0.014(2)$ & 0 & 0 & 0 \\
\hline $\mathrm{O}$ & $0.0292(10)$ & $0.0217(10)$ & $0.0200(9)$ & $-0.0061(7)$ & $0.0085(7)$ & $-0.0049(7)$ \\
\hline \multicolumn{7}{|c|}{ split-O model } \\
\hline $\mathrm{Ca}$ & $0.0163(5)$ & $0.0136(4)$ & $0.0136(4)$ & $0.0023(3)$ & 0 & 0 \\
\hline $\mathrm{Al}$ & $0.0178(4)$ & $0.0178(4)$ & $0.0178(4)$ & $-0.0033(3)$ & $0.0033(3)$ & $0.0033(3)$ \\
\hline $\mathrm{Si}$ & $0.015(3)$ & $0.014(2)$ & $0.014(2)$ & 0 & 0 & 0 \\
\hline $\mathrm{O} 1$ & $0.039(19)$ & $0.038(10)$ & $0.033(11)$ & $-0.023(8)$ & $0.016(10)$ & $-0.009(8)$ \\
\hline $\mathrm{O} 2$ & $0.018(2)$ & $0.0176(18)$ & $0.0165(16)$ & $-0.0017(13)$ & $0.0048(14)$ & $-0.0037(13)$ \\
\hline
\end{tabular}

of the $\mathrm{AlO}_{6}$ octahedral volume as a function of the Si content (Fig. 7). This result seemed to be quite reasonable considering the characteristics of a garnet structure. A garnet structure has an infinite chain composed of edge-sharing tetrahedra and dodecahedra running along every axis (Fig. 2). The $\mathrm{AlO}_{6}$ octahedra are located between the infinite chains. With increasing Si content, not only the $\mathrm{TO}_{4}$ tetrahedron but also the $\mathrm{CaO}_{8}$ dodecahedron were gradually contracted within the structure (Fig. 7). Because the chains running throughout the structure were contracted, the Al-O bonds were expanded between the shrinking chains. Consequently, the $\mathrm{AlO}_{6}$ octahedral volume slightly increased with the Si content although the unit cell volume decreased. The $\mathrm{CaO}_{8}, \mathrm{AlO}_{6}$, and $\mathrm{TO}_{4}$ polyhedra can be continuously and anisotropically changed in grossular and $\mathrm{Si}$-free katoite solid solution. This fact suggests that there is no geometrical constraint resulting in a miscibility gap. The $\mathrm{AlO}_{6}$ volume seems to reach a maximum value at 2.0 Si apfu in the crystal (Fig. 7), but at present no definite explanation could be offered.

\section{EPMA and Raman spectroscopic analysis}

The chemical compositions of katoite as determined using EPMA are given in Table 6. They show a similar chemical trend as determined through $\mathrm{X}$-ray crystal structure refinements, but went beyond the range of the standard deviations. Because the same single crystals were applied to both X-ray diffraction and EPMA, these differences were thought to result from analytical errors. In general, the surface effect on a quantitative analysis is significant for EPMA measurements. In this study, no surface polishing procedure could be conducted owing to the small crystal size, especially samples from Run 
196

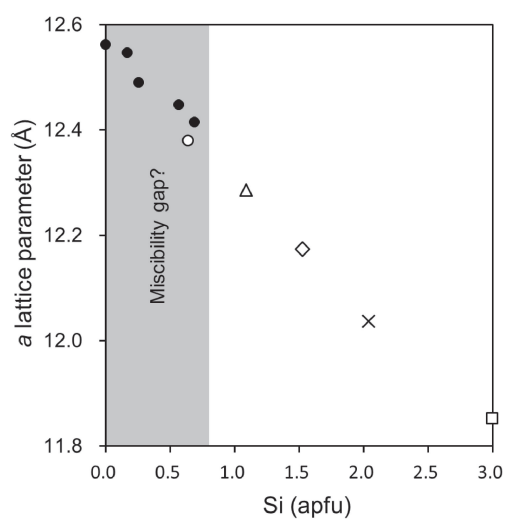

Figure 6. Variation of the $a$ lattice parameter in the solid solution between grossular and $\mathrm{Si}$-free katoite. Filled circles correspond to the data applied in this study. Open circle, open triangle, open diamond, cross symbol, and open square correspond to the data from Sacerdoti and Passaglia (1985), Ferro et al. (2003), Basso et al. (1983), Chakhmouradian et al. (2008), and Ganguly et al. (1993), respectively. The range of the miscibility gap is assumed by Kyritsis et al. (2009). Standard deviations (given in Table 1) are smaller than the size of symbols.
A. Kyono and S. Arora

1. The differences in the chemical composition between the X-ray data and EPMA would be therefore ascribed to the surface roughness. Although no appropriate quantitative data could be obtained through the EPMA measurement, the $\mathrm{Si} K \alpha$ line was clearly observed from each katoite. Moreover, these quantitative results suggested a $\mathrm{Ca}$ deficiency in the katoite. Thus, we attempted to refine the site occupancy factor for $\mathrm{Ca}$, but no significant deviation was shown from the full occupation. The site occupancy factor for $\mathrm{Al}$ was also refined, but did not vary significantly from 1.00 . The factors were therefore fixed at 1.00 for the least-squares refinements.

Figure 9 shows the Raman spectra and their peak fitting results within the frequency regions of the lattice mode and $\mathrm{OH}$ stretching vibration mode. In the previous Raman spectroscopic study on $\mathrm{Si}$-free katoite (Kolesov and Geiger, 2005; Kato and Kyono, 2019), three characteristic Raman peaks were observed around 335, 540, and $3650 \mathrm{~cm}^{-1}$. The Raman bands at $335 \mathrm{~cm}^{-1}$ and $540 \mathrm{~cm}^{-1}$

Table 4. Selected interatomic distances $(\AA)$ and polyhedral volumes $\left(\AA^{3}\right)$ in grossular-Si-free katoite solid solution

\begin{tabular}{|c|c|c|c|c|c|c|c|}
\hline \multirow[b]{2}{*}{ Si apfu ${ }^{a}$} & \multirow{2}{*}{$\begin{array}{c}\text { Kt03 } \\
0.00\end{array}$} & \multirow{2}{*}{$\begin{array}{c}\text { Run1_4 } \\
0.17\end{array}$} & \multirow{2}{*}{$\begin{array}{c}\text { Run1_2 } \\
0.26\end{array}$} & \multicolumn{2}{|c|}{ Run2 2} & \multicolumn{2}{|c|}{ Run2_3 } \\
\hline & & & & 0.57 & 0.59 & 0.69 & 0.69 \\
\hline Tetrahedron & & & & unsplit-O model & split-O model & unsplit-O model & split-O model \\
\hline$T^{b}-O^{c} \times 4$ & $1.957(2)$ & $1.948(2)$ & $1.932(2)$ & $1.9069(19)$ & $1.70(4)$ & $1.889(2)$ & $1.70(4)$ \\
\hline$T^{\mathrm{b}}-\mathrm{O}^{\mathrm{d}} \times 4$ & & & & & $1.935(9)$ & & $1.922(11)$ \\
\hline Volume $e^{\mathrm{c}}$ & 3.80 & 3.76 & 3.67 & 3.53 & 2.49 & 3.43 & 2.53 \\
\hline Volume $^{d}$ & & & & & 3.68 & & 3.60 \\
\hline \multicolumn{8}{|l|}{ Octahedron } \\
\hline $\mathrm{Al}-\mathrm{O}^{\mathrm{c}} \times 6$ & $1.913(2)$ & $1.911(2)$ & $1.909(2)$ & $1.9118(19)$ & $2.03(5)$ & $1.915(2)$ & $2.02(4)$ \\
\hline $\mathrm{Al}-\mathrm{O}^{\mathrm{d}} \times 6$ & & & & & $1.898(11)$ & & $1.898(11)$ \\
\hline Volume & 9.16 & 9.22 & 9.21 & 9.27 & 11.05 & 9.32 & 10.84 \\
\hline Volume $^{\mathrm{d}}$ & & & & & 9.02 & & 9.03 \\
\hline \multicolumn{8}{|l|}{ Dodecahedron } \\
\hline $\mathrm{Ca}-\mathrm{O}^{\mathrm{c}} \times 4$ & $2.463(2)$ & $2.462(2)$ & $2.448(2)$ & $2.441(2)$ & $2.56(4)$ & $2.435(2)$ & $2.56(4)$ \\
\hline $\mathrm{Ca}-\mathrm{O}^{\mathrm{c}} \times 4$ & $2.513(2)$ & $2.510(2)$ & $2.502(2)$ & $2.506(2)$ & $2.61(4)$ & $2.506(3)$ & $2.59(4)$ \\
\hline $\mathrm{Ca}-\mathrm{O}^{\mathrm{d}} \times 4$ & & & & & $2.428(9)$ & & $2.412(10)$ \\
\hline $\mathrm{Ca}-\mathrm{O}^{\mathrm{d}} \times 4$ & & & & & $2.494(9)$ & & $2.495(9)$ \\
\hline Volume $^{\mathrm{c}}$ & 25.96 & 25.77 & 25.47 & 25.49 & 28.70 & 25.45 & 28.31 \\
\hline Volume $^{d}$ & & & & & 25.07 & & 24.93 \\
\hline
\end{tabular}

${ }^{a}$ The $\mathrm{Si}$ apfu values are estimated from the site occupancy factors of Si. ${ }^{\mathrm{b}}$ The center of $T$ site (Wycoff position $24 d$ in space group $I a \overline{3} d$ ). ${ }^{\mathrm{c}}$ The $\mathrm{O}$ corresponds to the $\mathrm{O} 1$ in the split-O model. ${ }^{\mathrm{d}}$ The $\mathrm{O}$ corresponds to the $\mathrm{O} 2$ in the split-O model.

\begin{tabular}{|c|c|c|c|c|c|}
\hline Si apfúj & $\begin{array}{c}\text { Katoite }^{\mathrm{e}} \\
0.64\end{array}$ & $\begin{array}{c}\text { Katoite }^{f} \\
1.09\end{array}$ & $\begin{array}{c}\text { Hibschiteg }^{g} \\
1.53\end{array}$ & $\begin{array}{l}\text { Hibschite }^{\mathrm{h}} \\
2.05\end{array}$ & $\begin{array}{c}\text { Grossular }^{\mathrm{i}} \\
3.00\end{array}$ \\
\hline \multicolumn{6}{|l|}{ Tetrahedron } \\
\hline$T^{\mathrm{k}}-\mathrm{O} \times 4$ & $1.892(2)$ & $1.828(1)$ & $1.775(1)$ & $1.711(4)$ & $1.653(2)$ \\
\hline Volume & 3.45 & 3.12 & 2.84 & 2.54 & 2.29 \\
\hline \multicolumn{6}{|l|}{ Octahedron } \\
\hline $\mathrm{Al}-\mathrm{O} \times 6$ & $1.902(2)$ & $1.9171(9)$ & $1.927(1)$ & $1.929(4)$ & $1.924(2)$ \\
\hline Volume & 9.12 & 9.41 & 9.54 & 9.58 & 9.50 \\
\hline \multicolumn{6}{|c|}{ Dodecahedron } \\
\hline $\mathrm{Ca}-\mathrm{O} \times 4$ & $2.429(1)$ & $2.4037(9)$ & $2.383(1)$ & $2.351(5)$ & $2.318(2)$ \\
\hline $\mathrm{Ca}-\mathrm{O} \times 4$ & $2.497(3)$ & $2.4996(9)$ & $2.503(1)$ & $2.511(5)$ & $2.485(2)$ \\
\hline Volume & 25.19 & 25.13 & 24.88 & 24.65 & 23.78 \\
\hline
\end{tabular}

${ }^{\mathrm{e}}$ Sacerdoti and Passaglia (1985). ${ }^{\mathrm{f}}$ Ferro et al. (2003). ${ }^{\mathrm{g}}$ Basso et al. (1983). ${ }^{\mathrm{h}}$ Chakhmouradian et al. (2008). ${ }^{\mathrm{I}}$ Ganguly et al. (1993).

${ }^{\mathrm{j}}$ The Si apfu values are estimated from the site occupancy factors of Si. ${ }^{\mathrm{k}}$ The center of $T$ site (Wycoff position $24 d$ in space group $I a \overline{3} d$ ). 
Table 5. The O-O edge distances $(\AA)$ of each coordination polyhedron in the solid solution between grossular and Si-free katoite

\begin{tabular}{|c|c|c|c|c|c|c|c|c|c|c|}
\hline Si apfug & $\begin{array}{l}\text { Kt03 } \\
0.00\end{array}$ & $\underset{0.17}{\text { Runl } 4}$ & $\begin{array}{c}\text { Runl_2 } \\
0.26\end{array}$ & $\begin{array}{c}\text { Run2 } 22^{\mathrm{a}} \\
0.5 \overline{7}\end{array}$ & $\begin{array}{c}\text { Run2 } 23^{\mathrm{a}} \\
0.69\end{array}$ & $\begin{array}{c}\text { Katoite }^{b} \\
0.64\end{array}$ & $\begin{array}{c}\text { Katoite }^{\mathrm{c}} \\
1.09\end{array}$ & $\begin{array}{c}\text { Hibschite }^{d} \\
1.53\end{array}$ & $\begin{array}{c}\text { Hibschite }^{\mathrm{e}} \\
2.05\end{array}$ & $\begin{array}{c}\text { Grossularf }^{f} \\
3.00\end{array}$ \\
\hline \multicolumn{11}{|l|}{ Tetrahedron } \\
\hline $\mathrm{O}(1)-\mathrm{O}(2)$ & $3.067(3)$ & $3.058(3)$ & $3.030(3)$ & $2.992(4)$ & $2.963(4)$ & $2.969(4)$ & $2.863(2)$ & $2.775(2)$ & $2.665(7)$ & $2.575(3)$ \\
\hline $\mathrm{O}(1)-\mathrm{O}(3)$ & $3.258(3)$ & $3.241(3)$ & $3.215(3)$ & $3.173(4)$ & $3.143(4)$ & $3.147(4)$ & $3.044(2)$ & $2.957(2)$ & $2.855(7)$ & $2.758(3)$ \\
\hline \multicolumn{11}{|l|}{ Octahedron } \\
\hline $\mathrm{O}(1)-\mathrm{O}(4)$ & $2.591(3)$ & $2.594(3)$ & $2.596(3)$ & $2.615(4)$ & $2.630(4)$ & $2.608(4)$ & $2.660(2)$ & $2.701(2)$ & $2.736(7)$ & $2.749(3)$ \\
\hline $\mathrm{O}(1)-\mathrm{O}(5)$ & $2.815(2)$ & $2.806(3)$ & $2.801(3)$ & $2.789(4)$ & $2.785(4)$ & $2.769(4)$ & $2.761(1)$ & $2.750(2)$ & $2.721(7)$ & $2.694(3)$ \\
\hline \multicolumn{11}{|c|}{ Dodecahedron } \\
\hline $\mathrm{O}(1)-\mathrm{O}(2)$ & $3.067(3)$ & $3.058(3)$ & $3.030(3)$ & $2.992(4)$ & $2.963(4)$ & $2.969(4)$ & $2.863(2)$ & $2.775(2)$ & $2.665(7)$ & $2.575(3)$ \\
\hline $\mathrm{O}(1)-\mathrm{O}(4)$ & $2.591(3)$ & $2.594(3)$ & $2.596(3)$ & $2.615(4)$ & $2.630(4)$ & $2.608(4)$ & $2.660(2)$ & $2.701(2)$ & $2.736(7)$ & $2.749(3)$ \\
\hline $\mathrm{O}(1)-\mathrm{O}(6)$ & $3.736(2)$ & $3.729(2)$ & $3.707(2)$ & $3.6895(15)$ & $3.6745(16)$ & $3.669(4)$ & $3.6161(6)$ & $3.573(1)$ & $3.517(4)$ & $3.451(2)$ \\
\hline $\mathrm{O}(2)-\mathrm{O}(6)$ & $3.059(4)$ & $3.060(5)$ & $3.043(5)$ & $3.046(4)$ & $3.043(4)$ & $3.038(5)$ & $3.021(2)$ & $3.011(2)$ & $3.004(10)$ & $2.963(5)$ \\
\hline $\mathrm{O}(4)-\mathrm{O}(6)$ & $3.029(4)$ & $3.017(5)$ & $3.003(5)$ & $2.992(5)$ & $2.982(4)$ & $2.977(5)$ & $2.951(2)$ & $2.931(2)$ & $2.921(10)$ & $2.868(5)$ \\
\hline $\mathrm{O}(6)-\mathrm{O}(7)$ & $4.029(4)$ & $4.031(5)$ & $4.021(5)$ & $4.041(5)$ & $4.050(5)$ & $4.030(6)$ & $4.063(2)$ & $4.092(2)$ & $4.125(10)$ & $4.107(5)$ \\
\hline
\end{tabular}

Symmetry codes: (1) $x+1 / 4,-z+3 / 4,-y+1 / 4$; (2) $x+1 / 4, z+1 / 4, y+1 / 4$; (3) $-x+1 / 2, y,-z$; (4) $-z+3 / 4,-y+1 / 4, x+1 / 4$; (5) $z+3 / 4, y+1 / 4,-x+1 / 4$; (6) $z+1 / 2, x,-y+1 / 2 ;(7)-z+3 / 4, y+3 / 4,-x+1 / 4$.

${ }^{a}$ The O-O edge distances are taken from the unsplit-oxygen model. ${ }^{b}$ Sacerdoti and Passaglia (1985). ${ }^{c}$ Ferro et al. (2003). ${ }^{d}$ Basso et al. (1983). ${ }^{\mathrm{e}}$ Chakhmouradian et al. (2008). ${ }^{\mathrm{f}}$ Ganguly et al. (1993). ${ }^{\mathrm{g}}$ The Si apfu are estimated from the site occupancy factors of Si.
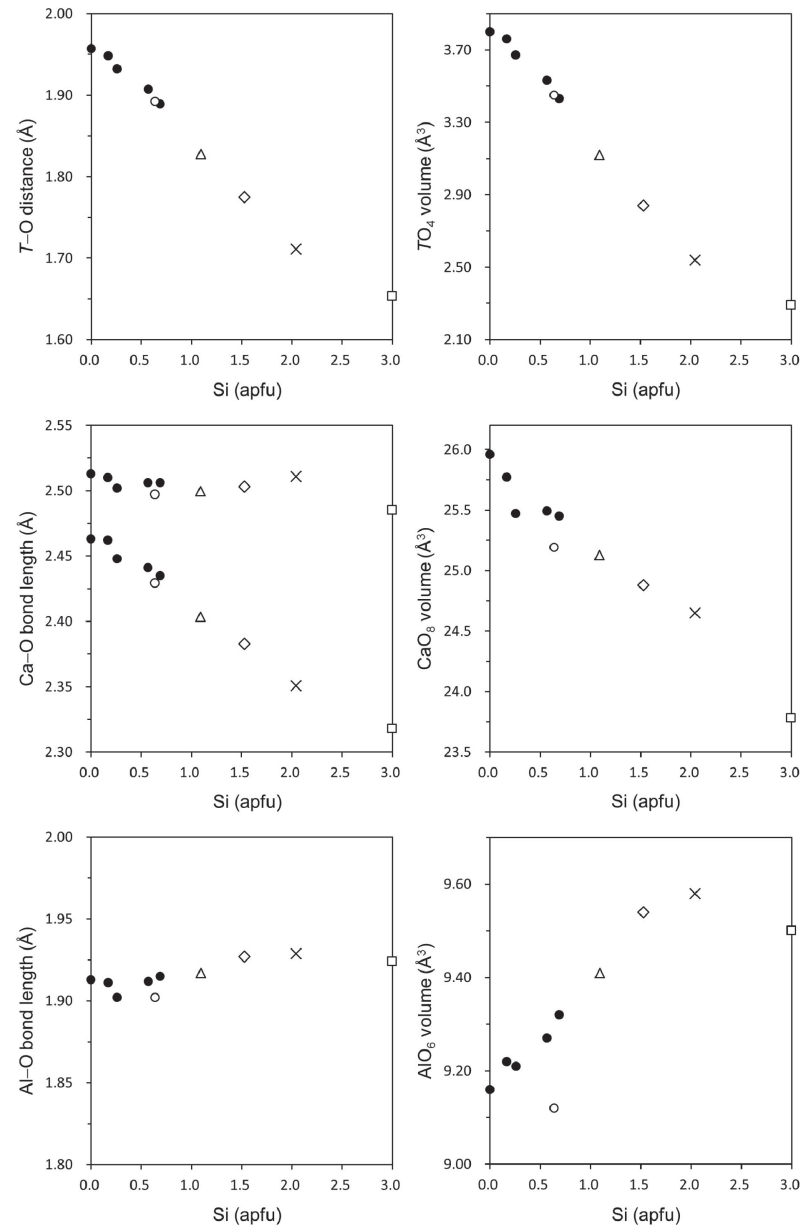

Figure 7. Variations of the bond distances and coordination polyhedral volumes in the solid solution between grossular and $\mathrm{Si}^{-}$ free katoite. Legends are provided in Figure 6. The data of Run 2_2 and Run 2_3 are taken from the unsplit-oxygen model. correspond to the $\mathrm{R}\left(\mathrm{O}_{4} \mathrm{H}_{4}\right)$ mode of the $A_{1 g}$ symmetry and the $\mathrm{T}(\mathrm{OH})$ motions of both $A_{1 g}+E_{g}$ and $F_{2 g}$ symmetries, respectively. The band at $3650 \mathrm{~cm}^{-1}$ can be assigned to the $\mathrm{OH}$ stretching modes of the $A_{1 g}+E_{g}$ and $F_{2 g}$ symmetries. The small Raman peak observed at 387 $\mathrm{cm}^{-1}$ can be assigned to the mixed $\mathrm{T} / \mathrm{R}\left(\mathrm{O}_{4} \mathrm{H}_{4}\right)$ mode of the $F_{2 g}$ symmetry. Here, several important points should be emphasized. First, as indicated in Figure 9b, a new Raman peak appeared around $3580 \mathrm{~cm}^{-1}$ with the substitution of $\mathrm{Si}$ for $\mathrm{H}$, which was in complete agreement with that of the IR spectroscopic study (Rossman and Aines, 1991). If the strength of hydrogen bonding decreases with the Si substitution for $\mathrm{H}$, the Raman peak must be gradually shifted toward higher frequencies. Surprisingly, the positions of the Raman bands around $3640 \mathrm{~cm}^{-1}$ and $3655 \mathrm{~cm}^{-1}$ remained approximately unchanged. Because the Raman peaks were observed at two clearly distinguishable regions, namely, $3580 \mathrm{~cm}^{-1}$ and $3650 \mathrm{~cm}^{-1}$, this result strongly suggests that there are two types of $\mathrm{OH}$ stretching vibrations that occur in the katoite. It is known that the $\mathrm{OH}$ stretching vibration in a hydrogarnet is significantly influenced by the neighboring cations (Rossman and Aines, 1991). Thus, this can be explained by the atomic mass effect in which a Raman peak is shifted toward lower wavenumbers with increasing atomic mass (Geiger and Rossman, 2018). That is, the $\mathrm{OH}$ stretching vibration with a lower frequency of 3580 $\mathrm{cm}^{-1}$ corresponds to the heavier atomic mass, whereas that with a higher frequency of $3650 \mathrm{~cm}^{-1}$ is ascribed to a lighter atomic mass. In the $\mathrm{Si}$-free katoite, the $\mathrm{O}$ is coordinated by two $\mathrm{Ca}$ atoms, one $\mathrm{Al}$ atom, and one $\mathrm{H}$ atom. The XRD measurements revealed that, with the Si 

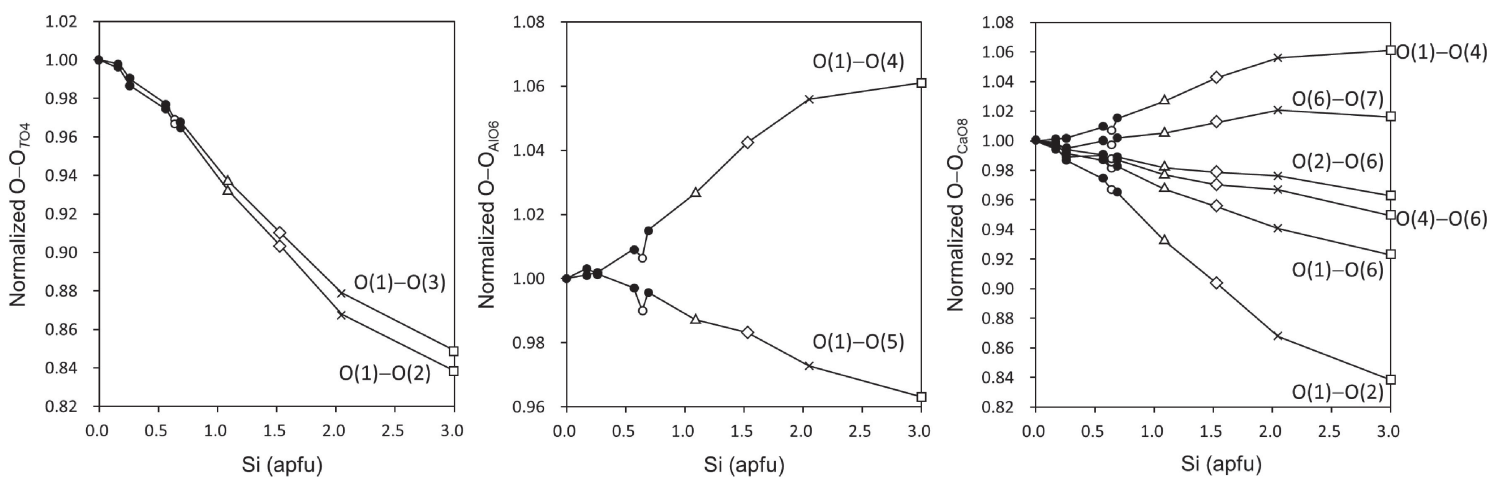

Figure 8. Variations of normalized $\mathrm{O}-\mathrm{O}$ edge distances in coordination polyhedra in the solid solution between grossular and $\mathrm{Si}$-free katoite Legends are provided in Figure 6. The data of Run 2_2 and Run 2_3 are taken from the unsplit-oxygen model.

Table 6. Electron microprobe analysis for katoite obtained in this study

\begin{tabular}{|c|c|c|c|c|c|c|c|c|c|c|c|}
\hline \multirow{2}{*}{ Sample } & \multirow{2}{*}{$\begin{array}{c}\begin{array}{c}\text { Si-free } \\
\text { katoite }\end{array} \\
\text { ideal }\end{array}$} & \multicolumn{2}{|c|}{$\mathrm{Kt} 03$} & \multicolumn{2}{|c|}{ Run1_4 } & \multicolumn{2}{|c|}{ Run1_2 } & \multicolumn{2}{|c|}{ Run2_2 } & \multicolumn{2}{|c|}{ Run2_3 } \\
\hline & & 5 points & $\begin{array}{l}\text { Std. } \\
\text { dev. }\end{array}$ & 4 points & $\begin{array}{l}\text { Std. } \\
\text { dev. }\end{array}$ & 4 points & $\begin{array}{l}\text { Std. } \\
\text { dev. }\end{array}$ & 5 points & $\begin{array}{l}\text { Std. } \\
\text { dev. }\end{array}$ & 5 points & $\begin{array}{l}\text { Std. } \\
\text { dev. }\end{array}$ \\
\hline $\mathrm{CaO}$ & 44.50 & 43.60 & 0.25 & 41.09 & 1.31 & 39.08 & 1.29 & 37.79 & 0.80 & 37.14 & 1.32 \\
\hline $\mathrm{Al}_{2} \mathrm{O}_{3}$ & 26.94 & 27.60 & 0.61 & 27.11 & 1.64 & 28.02 & 0.55 & 26.41 & 1.73 & 27.16 & 2.01 \\
\hline $\mathrm{SiO}_{2}$ & 0.00 & - & & 5.03 & 0.35 & 6.41 & 0.68 & 11.80 & 1.21 & 13.37 & 1.30 \\
\hline Total & 71.44 & 71.20 & 0.85 & 73.22 & 2.99 & $\begin{array}{c}73.50 \\
O=12\end{array}$ & 2.11 & 76.00 & 2.01 & 77.67 & 3.01 \\
\hline $\mathrm{Ca}$ & 3.00 & 2.93 & 0.04 & 2.77 & 0.17 & 2.61 & 0.15 & 2.55 & 0.06 & 2.53 & 0.14 \\
\hline $\mathrm{Al}$ & 2.00 & 2.04 & 0.06 & 2.01 & 0.18 & 2.06 & 0.09 & 1.96 & 0.15 & 2.03 & 0.19 \\
\hline $\mathrm{Si}$ & 0.00 & - & - & 0.32 & 0.03 & 0.40 & 0.05 & 0.74 & 0.08 & 0.85 & 0.09 \\
\hline $\mathrm{H}$ & 12.00 & 12.03 & 0.26 & 11.18 & 0.96 & 11.01 & 0.69 & 10.07 & 0.69 & 9.45 & 0.99 \\
\hline
\end{tabular}
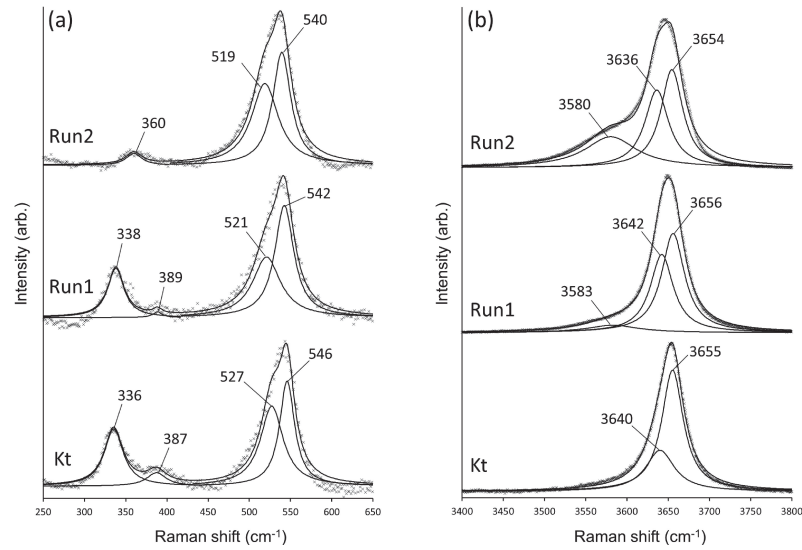

Figure 9. Raman spectra of katoite (Runs 1 and 2) and Si-free katoite $(\mathrm{Kt})$ in wavenumber regions of (a) lattice modes and (b) $\mathrm{OH}$ stretching vibration modes.

substitution for $\mathrm{H}$, the $\mathrm{O}$ position is split into two sites, $\mathrm{O} 1$ and $\mathrm{O} 2$. The $\mathrm{O} 1$ is coordinated by two $\mathrm{Ca}$ atoms, one $\mathrm{Al}$ atom, and one $\mathrm{Si}$ atom, resulting in a relatively heavier atomic mass. The $\mathrm{O} 2$ is, on the other hand, coordinated by two $\mathrm{Ca}$ atoms, one $\mathrm{Al}$ atom, and one $\mathrm{H}$ atom. In this case, two types of hydrogen bonding, namely, O2-H...O1 and $\mathrm{O} 2-\mathrm{H} \cdots \mathrm{O} 2$, are formed in the structure (Fig. 10). The

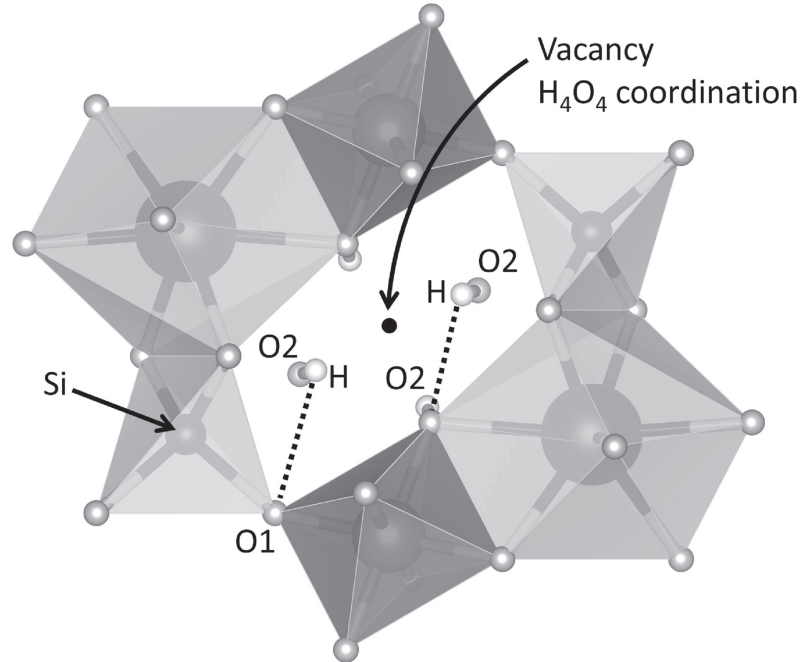

Figure 10. Local structure around $\mathrm{SiO}_{4}$ tetrahedron and $\mathrm{H}_{4} \mathrm{O}_{4}$ tetrahedral interstice.

hydrogen binding with $\mathrm{O} 1$ gives rise to a vibration with a lower frequency of $3580 \mathrm{~cm}^{-1}$, whereas that with $\mathrm{O} 2$ leads to a vibration with a higher frequency of 3650 $\mathrm{cm}^{-1}$. The splitting of the oxygen position into $\mathrm{O} 1$ and $\mathrm{O} 2$ is the reason why $\mathrm{OH}$ stretching vibrations were ob- 
served at two clearly distinguishable regions in the katoite. The second important feature of the Raman spectra can be seen in the lattice mode region (Fig. 9a). The Sifree katoite exhibited a Raman band at $387 \mathrm{~cm}^{-1}$, which can be assigned to the mixed $\mathrm{T} / \mathrm{R}\left(\mathrm{O}_{4} \mathrm{H}_{4}\right)$ mode. As increasing Si content, the peak seemed to broaden and finally disappear. The Raman bands at $336 \mathrm{~cm}^{-1}$ corresponding to the $\mathrm{R}\left(\mathrm{O}_{4} \mathrm{H}_{4}\right)$ mode also broadened and shifted to a higher frequency. These Raman bands would be sensitive to the substitution of $\mathrm{Si}$ for $\mathrm{H}$ in katoite, although further investigation is still required to confirm this result.

\section{CONCLUSIONS}

Single crystals of katoite with a continuous chemical composition up to $\mathrm{Ca}_{3} \mathrm{Al}_{2}\left(\mathrm{SiO}_{4}\right)_{0.69}\left(\mathrm{H}_{4} \mathrm{O}_{4}\right)_{2.31}$ were obtained using a hydrothermal method at $250{ }^{\circ} \mathrm{C}$. The compositions lie within the miscibility gap shown by Kyritsis et al. (2009). In katoite with chemical formulas of $\mathrm{Ca}_{3} \mathrm{Al}_{2}$ $\left(\mathrm{SiO}_{4}\right)_{0.57}\left(\mathrm{H}_{4} \mathrm{O}_{4}\right)_{2.43}$ and $\mathrm{Ca}_{3} \mathrm{Al}_{2}\left(\mathrm{SiO}_{4}\right)_{0.69}\left(\mathrm{H}_{4} \mathrm{O}_{4}\right)_{2.31}$, the $\mathrm{O}$ atom position was split into two independent crystallographic sites, $\mathrm{O} 1$ and $\mathrm{O} 2$. The $\mathrm{O} 1$ is coordinated with $\mathrm{Si}$, whereas the $\mathrm{O} 2$ forms a tetrahedral interstice. Raman bands corresponding to the $\mathrm{OH}$ stretching vibration were observed at $3580 \mathrm{~cm}^{-1}$ and $3650 \mathrm{~cm}^{-1}$. These two Raman band positions remained approximately unchanged with $\mathrm{Si}$ substitution for $\mathrm{H}$. These findings strongly support the results obtained through single-crystal XRD measurements.

\section{ACKNOWLEDGMENTS}

We sincerely appreciate the two anonymous reviewers for their constructive comments and valuable suggestions on improving the manuscript. The single-crystal synchrotron $\mathrm{X}$-ray diffraction experiment was approved by the Photon Factory Program Advisory Committee (Proposal Nos. 2015G049 and 2016G524). This work was partially supported by a Grant-in-Aid for Scientific Research (C) from the Japan Society for the Promotion of Science (Project No. JP17K05702).

\section{SUPPLEMENTARY MATERIALS}

Color versions of Figures 4 and 5 are available online from https://doi.org/10.2465/jmps. 190424.

\section{REFERENCES}

Ackermann, L., Cemič, L. and Langer, K. (1983) Hydrogarnet substitution in pyrope: a possible location for "water" in the mantle. Earth and Planetary Science Letters, 62, 208-214.

Adhikari, P., Dharmawardhana, C.C. and Ching, W.Y. (2017)
Structure and properties of hydrogrossular mineral series. Journal of the American Ceramic Society, 100, 4317-4330.

AISN (1995) PeakFit v.4.0 Documentation, Jandel Scientific Software, (C) 1995 AISN Software, San Rafael, CA, USA.

Armbruster, T. and Lager, G.A. (1989) Oxygen disorder and the hydrogen position in garnet-hydrogarnet solid solutions. European Journal of Mineralogy, 1, 363-369.

Armbruster, T., Kohler, T., Libowitzky, E., Friedrich, A., Miletich, R., Kunz, M., Medenbach, O. and Gutzmer, J (2001) Structure, compressibility, hydrogen bonding, and dehydration of the tetragonal $\mathrm{Mn}^{3+}$ hydrogarnet, henritermierite. American Mineralogist, 86, 147-158.

Basso, R., Giusta, A.D. and Zefiro, L. (1983) Crystal structure refinement of plazolite: a highly hydrated natural hydrogrossular. Neues Jahrbuch für Mineralogie, Monatshefte, 1983, 251258.

Bell, D.R. and Rossman, G.R. (1992) Water in Earth's mantle: the role of nominally anhydrous minerals. Science, 255, 13911397.

Bennett, D.G., Read, D., Atkins, M. and Glasser, F.P. (1992) A thermodynamic model for blended cements. II: Cement hydrate phases; thermodynamic values and modelling studies. Journal of Nuclear Materials, 190, 315-325.

Burnett, M.N. and Johnson, C.K. (1996) ORTEP-III: Oak Ridge thermal ellipsoid plot program for crystal structure illustrations. Report ORNL-6895, Oak Ridge National Laboratory, Oak Ridge, TN.

Bruker (1998) SHELXTL: structure determination programs Ver. 5.16. Bruker Analytical X-ray Instruments Inc., Madison, Wisconsin, USA.

Bruker (2006) APEX2 Version 2; Data collection and processing software. Bruker Analytical X-ray Instruments Inc., Madison, Wisconsin, USA.

Bruker (2008) SAINT Version 7.60A. Bruker Analytical X-ray Instruments Inc., Madison, Wisconsin, USA.

Chakhmouradian, A.R., Cooper, M.A., Medici, L., Hawthorne, F.C. and Adar, F. (2008) Fluorine-rich hibschite from silicocarbonatite, Afrikanda complex, Russia: crystal chemistry and conditions of crystallization. Canadian Mineralogist, 46, 1033-1042.

Cheng, W., Greenwood, H.J., Hu, H. and Frost, D.C. (1990) XRD and XPS analyses of the grossular-hydrogrossular series. Canadian Mineralogist, 28, 87-91.

Cohen-Addad, C., Ducros, P., Durif, A., Bertaut, E.F. and Delapalme, A. (1964) Détermination de la position des atomes d'hydrogène dans l'hydrogrinat $\mathrm{Al}_{2} \mathrm{O}_{3}, 3 \mathrm{CaO}, 6 \mathrm{H}_{2} \mathrm{O}$ par résonance magnétique nucléaire et diffraction neutronique. Journal de Physique, 25, 478-483.

Cohen-Addad, C., Ducros, P. and Bertaut, E.F. (1967) Étude de la substitution du groupement $\mathrm{SiO}_{4}$ par $(\mathrm{OH})_{4}$ dans les composés $\mathrm{Al}_{2} \mathrm{Ca}_{3}(\mathrm{OH})_{12}$ et $\mathrm{Al}_{2} \mathrm{Ca}_{3}\left(\mathrm{SiO}_{4}\right)_{2.16}(\mathrm{OH})_{3.36}$ de type grenat. Acta Crystallographica, 23,220-230.

Dilnesa, B.Z., Lothenbach, B., Renaudin, G., Wichser, A. and Kulik, D. (2014) Synthesis and characterization of hydrogarnet $\mathrm{Ca}_{3}\left(\mathrm{Al}_{\mathrm{x}} \mathrm{Fe}_{1-\mathrm{x}}\right)_{2}\left(\mathrm{SiO}_{4}\right)_{\mathrm{y}}(\mathrm{OH})_{4(3-\mathrm{y})}$. Cement and Concrete Research, 59, 96-111.

Ferro, O., Galli, E., Papp, G., Quartieri, S., Szakall, S. and Vezzalini, G (2003) A new occurrence of katoite and re-examination of the hydrogrossular group. European Journal of Mineralogy, 15, 419-426.

Flint, E.P., McMurdie, H.F. and Wells, L.S. (1941) Hydrothermal and X-ray studies of the garnet-hydrogarnet series and the 
relationship of the series to hydration products of portland cement. Journal of Research of the National Bureau of Standards, 26 13-33.

Geiger, C.A., Langer, K., Bell, D.R., Rossman, G.R. and Winkler, B. (1991) The hydroxide component in synthetic pyrope. American Mineralogist, 76, 49-59.

Geiger, C.A. and Rossman, G.R. (2018) IR spectroscopy and $\mathrm{OH}^{-}$ in silicate garnet: The long quest to document the hydrogarnet substitution. American Mineralogist, 103, 384-393.

Ganguly, J., Cheng, W. and O'Neill, H.St.C. (1993) Syntheses, volume, and structural changes of garnets in the pyrope-grossular join: Implications for stability and mixing properties. American Mineralogist, 78, 583-593.

Huang, X.G., Xu, Y.S. and Karato, S.I. (2005) Water content in the transition zone from electrical conductivity of wadsleyite and ringwoodite. Nature, 434, 746-749.

Hirth, G. and Kohlstedt, D.L. (1996) Water in the oceanic upper mantle: Implications for rheology, melt extraction and the evolution of the lithosphere. Earth and Planetary Science Letters, 144, 93-108.

Ingrin, J. and Skogby, H. (2000) Hydrogen in nominally anhydrous upper-mantle minerals: concentration levels and implications. European Journal of Mineralogy, 12, 543-570.

Jappy, T.G. and Glasser, F.P. (1991) Synthesis and stability of silica-substituted hydrogarnet $\mathrm{Ca}_{3} \mathrm{Al}_{2} \mathrm{Si}_{3-x} \mathrm{O}_{12-4 x}(\mathrm{OH})_{4 x}$. Advances in Cement Research, 4, 1-8.

Kato, M. and Kyono, A. (2019) An in situ Raman study on katoite $\mathrm{Ca}_{3} \mathrm{Al}_{2}\left(\mathrm{O}_{4} \mathrm{H}_{4}\right)_{3}$ at high pressure. Journal of Mineralogical and Petrological Sciences, 114, 18-25.

Kobayashi, S. and Shoji, T. (1982) Infrared analysis of the grossular-hydrogrossular series. Mineralogical Journal, 11, 331-343.

Kolesov, B.A. and Geiger, C.A. (2005) The vibrational spectrum of synthetic hydrogrossular (katoite) $\mathrm{Ca}_{3} \mathrm{Al}_{2}\left(\mathrm{O}_{4} \mathrm{H}_{4}\right)_{3}$ : A low-temperature IR and Raman spectroscopic study. American Mineralogist, 90, 1335-1341.

Kyritsis, K., Meller, N. and Hall, C. (2009) Chemistry and morphology of hydrogarnets formed in cement-based CASH hydroceramics cured at $200^{\circ}$ to $350^{\circ} \mathrm{C}$. Journal of American Ce- ramic Society, 92, 1105-1111.

Lacivita, V., Mahmoud, A., Erba, A., D'Arco, P. and Mustapha, S. (2015) Hydrogrossular, $\mathrm{Ca}_{3} \mathrm{Al}_{2}\left(\mathrm{SiO}_{4}\right)_{3-x}\left(\mathrm{H}_{4} \mathrm{O}_{4}\right)_{x}$ : An ab initio investigation of its structural and energetic properties. American Mineralogist, 100, 2637-2649.

Lager, G.A., Armbruster, T., Rotella, F.J. and Rossman, G.R. (1989) OH substitution in garnets: X-ray and neutron diffraction, infrared, and geometric-modeling studies. American Mineralogist, 74, 840-851.

Mackwell, S.J., Kohlstedt, D.L. and Paterson, M.S. (1985) The role of water in the deformation of olivine single-crystals. Journal of Geophysical Research: Solid Earth and Planets, 90, 13191333.

Passaglia, E. and Rinaldi, R. (1984) Katoite, a new member of the $\mathrm{Ca}_{3} \mathrm{Al}_{2}\left(\mathrm{SiO}_{4}\right)_{3}-\mathrm{Ca}_{3} \mathrm{Al}_{2}\left(\mathrm{SiO}_{4}\right)_{3}(\mathrm{OH})_{12}$ series and a new nomenclature for the hydrogrossular group of minerals. Bulletin de Minéralogie, 107, 605-618.

Rossman, G.R. and Aines, R.D. (1991) The hydrous components in garnets: Grossular-hydrogrossular. American Mineralogist, 76, 1153-1164.

Sacerdoti, M. and Passaglia, E. (1985) The crystal structure of katoite and implications within the hydrogrossular group of minerals. Bulletin de Minéralogie, 108, 1-8.

Sheldrick, G.M. (2014) SHELXL-2014/7: Program for the refinement of crystals structures, University of Göttingen, Germany.

Sheldrick, G.M. (1999) SADABS: Empirical absorption and correction software; University of Göttingen, Germany.

Shoji, T. (1974) $\mathrm{Ca}_{3} \mathrm{Al}_{2}\left(\mathrm{SiO}_{4}\right)_{3}-\mathrm{Ca}_{3} \mathrm{Al}_{2}\left(\mathrm{O}_{4} \mathrm{H}_{4}\right)_{3}$ series garnet: composition and stability. Journal of the Mineralogical Society of Japan, 11, 359-372 (in Japanese).

Wilkins, R.W.T. and Sabine, W. (1973) Water content of some nominally anhydrous silicates. American Mineralogist, 58, 508-516.

Manuscript received April 24, 2019

Manuscript accepted July 25, 2019

Published online September 10, 2019

Manuscript handled by Takaya Nagai 